\title{
Availability and the Use of Instructional Materials in the Teaching and Learning of Igbo Language
}

\section{Omeje, Monica Obiageli (Ph.d.)}

Department of Arts Education, University of Nigeria, Nsukka

Email: monica.omeje@gmail.com

\author{
Chineke, Stella Obioma \\ Department of Arts Education, University of Nigeria, Nsukka \\ Email: stella.chineke@unn.edu.ng
}

\section{Doi:10.5901/mjss.2015.v6n3s1p286}

\begin{abstract}
This study set out to identify the availability and extent of the use of instructional materials in the teaching and learning of lgbo language in Obollo-Afor Educational Zone. The work adopted a survey design and two research questions guided the study. Instrument for data collection was a researcher made questionnaire with 40 items. The data obtained were analyzed using percentage, mean and standard deviation. The results indicated that most of the instructional resources were not available in the schools, while the few available ones were utilized to low and very low extent. Based on the findings, it was recommended among others that government should provide resources for lgbo language instruction and that seminars and workshops should be organized for the teachers on the importance of using instructional materials in delivering their lessons.
\end{abstract}

Keywords: Instructional material, lgbo language, language.

\section{Introduction}

Language is a means of communication by which human beings interact and exchange their thoughts, ideas and feelings. In agreement, Anagbogu, Mbah and Ene (2002) defined language as a means devised by human beings for communicating their ideas, feelings, emotions and desires, through complex vocal or written symbols. Language is therefore an indispensable tool in any given human society. That is why Nwaozuzu (2008) referred to it as one of the most fundamental aspects of human behaviour. Though language is universal in human societies, every society is associated with one or more languages.

Igbo language is a language predominantly spoken in the Eastern part of Nigeria. It is one of the three major Nigerian languages learned in schools (FRN, 2004). Like every other language, the primary aim of teaching Igbo language in schools is to develop communication skills in the learners. To achieve the above objective, the subject must be properly taught in schools. One feature of good teaching of languages is the ability to inculcate in the learners the capability to use the language effectively in oral and written communications. This demands that the teacher should have adequate knowledge of the contents, methodology and appropriate usage of relevant instructional materials. Therefore, for effective teaching and learning of Igbo language in schools, the needed instructional materials should be available and be adequately used by the teachers.

Instructional materials are fundamental resources for schools for enhancing instruction, furthering the pursuit of knowledge, and providing experiences of educational significance for class groups or for individual students,( Miami-Dade County Bylaws And Policies, 2011). Similarly, Njoku (2000) defined instructional materials as any human and material resources used by the teacher to promote greater understanding of learning experience. They include resource persons and various materials like whiteboard, pictorials, flashcards, projector, slides, film stripe and language laboratory. This informs that for a given instructional procedure to achieve desired objectives, it must be properly harnessed through adequate and proper use of instructional facilities. Enem (2002) opined that nothing attracts and sustains the attention of the learners faster than the use of relevant resource materials. The use of adequate and relevant resource materials has many advantages. Instructional resources which are educational inputs are of vital importance to the teaching of any subject in the school curriculum. Jubay (2014) stated that Instructional Materials serve as the channel between the teacher and the students in delivering the instruction. They enhance teaching and learning, and makes lessons 
interesting and meaningful. They also save teacher's time and energy in giving out much information. They may also serve as the motivation on the teaching- learning process. Instructional materials are very important in Igbo language teaching because they facilitate the direct association between sounds and their symbols and also words and the objects they represent.

Despite the usefulness of instructional materials in the classroom, Mkpa (1987) observes that many teachers are very reluctant to use them in their teaching. He posits that many teachers use instructional materials last at the time they were being examined or supervised for certification. Now that such supervision is rarely done, they do not bother to use the resources any longer. Corroborating Mkpa's view, Enem (2001) opines that some teachers find it difficult to use instructional materials in delivering their lessons, probably due to lack of interest, resourcefulness or inadequate training on the need and how to use instructional materials. This goes a long way to reveal that the problem associated with the use of instructional materials in teaching is dove-tailed. The needed materials for Igbo language instruction may not be available, and even if they are, teachers may not use them due to ignorance or unwillingness to put in extra effort to enhance their professional competence. This therefore calls for an investigation into the availability and extent of utilization of instructional materials in the teaching and learning of Igbo language in Obollo-Afor Education Zone. In doing that, two research questions were posed to guide the study.

$>$ What are the available instructional materials for the teaching of Igbo language in Obollo-Afor Education Zone?

$>$ To what extent do Igbo language teachers use the available instructional materials in Igbo language teaching and learning?

\section{Method}

A descriptive survey design was adopted for the study. The choice of this design is based on the fact that it would enable the researchers to collect and analyze data as they are without any manipulation. According to Ali (2006), this type of research design involves describing events as they are without any manipulation of what caused the events or what is being observed. The research subjects were 213 Igbo language teachers in Obollo-Afor Education Zone, purposively sampled for the study. Instrument for data collection were a researcher made questionnaire and a checklist.

The researchers used the checklist to identify the available instructional materials while the questionnaire was used to elicit information on the extent of utilization of the available instructional materials. The questionnaire had two clusters with 40 items. Response options for items in cluster $A$ are $A=$ Available, NA= Not Available, whereas options for those in cluster $B$ are Very High Extent $(V H E)=4$ points, High Extent $(H E)=3$ points, Low Extent $(L E)=2$ points, Very Low Extent $(\mathrm{VLE})=1$ point and Not At All (NAA) $=0$ point.

The collected data were analyzed using percentage, mean and standard deviation. Any mean above 4.99= VHE, 3.50-4.99= HE, 3.00-3.49= LE while 2.50-2.99= VLE. For research question 1, 50\% and above is accepted. Also, for research question 2, any mean score of 2.50 and above is accepted but any one below 2.50 is not accepted.

\section{Results}

Findings from the study are presented based on the research questions.

Research Question 1: What are the available instructional materials for the teaching of Igbo language in ObolloAfor Education Zone?

Table 1: Percentage of the available instructional materials for Igbo language instruction

\begin{tabular}{ccccccc}
\hline S/N & VISUAL MATERIALS & A & NA & $\% A$ & $\%$ NA & DECISION \\
\hline 1 & Textbooks & 213 & 0 & 100 & 0 & A \\
2 & Chalkboard & 213 & 0 & 100 & 0 & A \\
3 & Whiteboard & 12 & 201 & 5.60 & 94.40 & NA \\
4 & Pictures & 213 & 0 & 100 & 0 & A \\
5 & Projector & 0 & 213 & 0 & 100 & NA \\
6 & Film strip & 0 & 213 & 0 & 100 & NA \\
7 & Flash cards & 178 & 35 & 83.7 & 16.3 & A \\
& AUDIO MATERIALS & A & NA & $\%$ A & $\%$ NA & DECIAION \\
8 & Audio cassettes & 24 & 189 & 11.30 & 88.7 & NA \\
9 & Audio cassette recorder & 0 & 213 & 0 & 100 & NA \\
\hline & & & & & \\
& & -0 & & & &
\end{tabular}




\begin{tabular}{ccccccc}
\hline 10 & Audio compact disc & 0 & 213 & 0 & 100 & NA \\
11 & Radio & 2 & 211 & 0.94 & 99.06 & NA \\
1 & Speaker & 0 & 213 & 0 & 100 & NA \\
& AUDIO/VISUAL MATERIALS & A & NA & $\%$ A & $\%$ NA & DECISION \\
13 & Television & 0 & 213 & 0 & 100 & NA \\
14 & Video cassette & 0 & 213 & 0 & 100 & NA \\
15 & Video cassette recorder & 0 & 213 & 0 & 100 & NA \\
16 & Video compact disc & 0 & 213 & 0 & 100 & NA \\
17 & Video compact disc player & 0 & 213 & 0 & 100 & NA \\
18 & INTERACTIVE MEDIA & A & NA & $\% A$ & $\%$ NA & DECISION \\
19 & Computer & 3 & 210 & 1.41 & 98.59 & NA \\
20 & Language laboratory & 0 & 213 & 0 & 100 & NA \\
Decision $=\mathrm{A} \rightarrow$ Available, NA $\rightarrow$ Not Available & Starboard & & & & & NA \\
\hline
\end{tabular}

Table 1 reveals that items number 1, 2, 4 and 7 are available for Igbo language instruction hence their percentage are $100 \%, 100 \%, 100 \%$ and $83.7 \%$ respectively. This shows that among the 20 instructional materials listed, only textbooks, chalkboard, pictures and flash cards are available while the other 16 items are not available because their percentage are below 50 .

Research Question 2: To what extent do Igbo language teachers use the available instructional materials in Igbo language teaching and learning?

Table 2: Mean scores of extent of utilization of available instructional materials for Igbo language teaching and learning.

\begin{tabular}{cccccc}
\hline S/N & VISUAL MATERIALS & $\mathbf{N}$ & MEAN & SD & DECISION \\
\hline 1 & Textbooks & 213 & 3.17 & 0.63 & U (S) \\
2 & Chalkboard & 213 & 3.06 & 0.66 & U (S) \\
3 & Whiteboard & 213 & 1.32 & 0.60 & NU \\
4 & Pictures & 213 & 3.08 & 0.79 & U (S) \\
5 & Projector & 213 & 1.50 & 0.76 & NU \\
6 & Film strip & 213 & 1.33 & 0.60 & NU \\
7 & Flash cards & 213 & 2.79 & 0.86 & U (R) \\
& AUDIO MATERIALS & $\mathbf{N}$ & MEAN & SD & DECISION \\
8 & Audio cassettes & 213 & 1.07 & 0.25 & NU \\
9 & Audio cassette recorder & 213 & 1.23 & 0.66 & NU \\
10 & Audio compact disc & 213 & 1.32 & 0.60 & NU \\
11 & Radio & 213 & 1.48 & 0.89 & NU \\
12 & Speaker & 213 & 1.47 & 0.77 & NU \\
& N & MEAN & SD & DECISION \\
13 & AUDIO/VISUAL MATERIALS & 213 & 1.33 & 0.60 & NU \\
14 & Television & 213 & 1,31 & 0.60 & NU \\
15 & Video cassette & 213 & 1.06 & 0.26 & NU \\
16 & Video cassette recorder & 213 & 1.24 & 0.68 & NU \\
17 & Video compact disc & 213 & 1.29 & 0.60 & NU \\
& Video compact disc player & N & MEAN & SD & DECISION \\
18 & INTERACTIVE MEDIA & 213 & 1.49 & 0.89 & NU \\
19 & Computer & 213 & 1.45 & 0.73 & NU \\
20 & Language laboratory & 213 & 1.35 & 0.64 & NU \\
\hline
\end{tabular}

Decision $=\mathrm{U} \rightarrow$ Utilized, $\mathrm{NU} \rightarrow$ Not Utilized

Table 2 shows that the available instructional materials namely textbooks, chalkboard, pictures and flash cards are utilized by Igbo language teacher while the other 16 unavailable items are not utilized. However, the available ones are not adequately utilized hence, items number 1, 2 and 4 are utilized to low extent because their means are within the range of 3.00 and 3.49. Also item number 7 is utilized to a very low extent because the mean is 2.79 .

\section{Discussion}

The analyzed data showed that the available instructional materials for Igbo language instruction are textbooks, 
chalkboard, pictures and flash cards. Other visual materials are not available. Also, the audio, audio/visuals and interactive media are not available. Although there are some resources, it is obvious that most of the needed instructional materials for Igbo language instruction are not available. This finding is in line with Ezike (2006) who noted that most schools do not have many resources.

The study further revealed that the 4 available instructional resources are utilized while the 16 unavailable ones are not utilized. However, the teachers are not using those available ones adequately because textbooks, chalkboard and pictures are utilized to a low extent while flash cards are used to a very low extent. This is an indication that if efforts are made to provide more resources, the teachers may not still use them adequately. Gistarea (2013) lamented that ineffective utilization of the available instructional materials is a major concern to the society. He opined that for a given instructional procedure to achieve desired objectives, it must be properly harnessed through adequate and proper use of instructional facilities. This is a truism because the use of instructional materials gives the students the opportunity to see, feel and touch the materials which in turn makes the lesson to be real.

\section{Recommendations}

Based on the findings of the study, the following are recommended:

- Government and school authorities should provide instructional materials to enhance teaching and learning of Igbo language;

- Seminars and workshops on the use of instructional materials should be organized for Igbo language teachers;

- Teachers and students should be encouraged to form the habit of improvising instructional materials to make up the shortfall in supply.

\section{Conclusion}

From the findings of the study, it can be seen that only very few instructional materials, especially visual aids are available for the teaching and learning of Igbo language. Also, the available ones are not adequately utilized. Therefore, unavailability and inadequate use of instructional resources could be one of the factors militating against effective teaching and learning of the language.

\section{References}

Ali, A. (2006). Conducting research in education and the social sciences. Enugu: Tashiwa Networks.

Anagbogu, P. N., Mbah, B. M. \& Eme, C. A. (2001). Introduction to linguistics. Awka: J. F. C. Limited.

Ene, F. N. (2002). "Effect of cloze instructional approach on senior secondary school students' achievement in English reading comprehension." M. Ed. Project, University of Nigeria, Nsukka.

Enem, F. O. (2001). "Teachers' possession of competencies required for effective teaching of Social Studies curriculum in Enugu State." Ph. D. Thesis, Enugu State University of Science and Technology.

Enem, F. O. (2002). Teaching in primary school. Lagos: Longman.

Ezike, S. M. (2006). "Extent of the use of instructional materials in the teaching of Social Studies." M.Ed project, University of Nigeria, Nsukka.

Federal Republic of Nigeria. (2004). National policy on education. Lagos: NERDC Press.

Gistarea, (2013). Instructional materials in teaching -uses, learning and importance. Retrieved from http:/luww.gistarea.com/ instructional-materials-teaching-examples-importance/

Jubay, A. (2014). What are the importance of instructional materials? Retrieved from http://www.answers.com/Q/What_are_the_ importance_of_instructional_materials

Mkpa, M. A. (1996). Community resources in junior secondary school: Alternative in resources utilization. In E. A. Imogie et al (Eds.), Friends and Research in Educational Technology. Ibadan: Y-Books.

Njoku, A. O. (2000). A textbook on Social Studies. Enugu: Computer Edge Publishers.

Nwaozuzu, G. I. (2008). Dialects of Igbo language. Nsukka: University of Nigeria Press Ltd.

The School Board of Miami-Dade County Bylaws \& Policies (2011). Instructional materials and resources. Retrieved from http://www.neola.com/miamidade-fl/search/policies/po2510.htm 